\title{
On the Role and Function of Augustine's Inwardness in the Constitution of Descartes' Cogito
}

Teixeira $\mathbf{W}^{*}$

University of Brasilia, Brazil

*Corresponding author: William Teixeira, University of Brasilia, SHIGS 705 Block H House 62, Brasilia, Federal District, Brazil, Tel: (61) 99599-1803; Email: william.unb@hotmail.com

\section{Research Article}

Volume 3 Issue 1

Received Date: February 12, 2020

Published Date: March 03, 2020

DOI: $10.23880 /$ phij-16000139

\section{Abstract}

The main aim of this paper is to show how 'Augustinian inwardness' has played a decisive role in the constitution of Descartes' cogito. So I will first hold that Descartes has borrowed this inward feature of Augustine's thought and developed from it a method of introspection which is widely used in his Meditations on first philosophy. Next, I will show that it will be by subordinating the simple natures to the subject of inherence issued from the mind-body distinction undertaken under the influence of Augustinian inwardness that Descartes will shape the metaphysical notion of res cogitans (thinking substance). In the end, it will be clear that Augustine' inwardness helps us understand not only how 'thought' was raised to the ontological role it plays in Descartes' metaphysics, but also why it has ontological priority among the other intellectual simple natures.

Keywords: Descartes; Augustine; Inwardness; Introspection; Simple Natures; Cogito

In his monumental work about the origins and constitution of the notion of 'self' in western world, Charles Taylor eventually engages in the problematic relationship between Descartes' and Augustine's philosophies. Even though he does not seem to have a deliberate polemical purpose in mind he vehemently asserts that the Bishop of Hippo exerted a decisive influence on the French philosopher: "Plainly the whole Cartesian project owes a great deal to its Augustinian roots and the enhanced place this tradition gave to inwardness" (Taylor, 1989, p. 156). In my view, Taylor's statement is quite correct. To begin with, the title of Descartes' master-piece, the work in which Augustinian inwardness is arguably ubiquitous, that is, the Meditations on First Philosophy ${ }^{1}$, seems already to suggest the inward approach in which his reflections will be carried out. Accordingly, for those who grasp this link between the title of Descartes' work on metaphysics and a possibly inward approach that will be adopted to it, it comes as no surprise to see that an overwhelming first-person standpoint is clearly recognizable throughout the Meditations. From the 'methodical doubt' in the First Meditation to the

1 Henceforth just Meditations. demonstration of the real distinction between mind and body in the Sixth Meditation it is manifest that Descartes is imbued with a kind of 'introspective method' that seems to be issued from that Augustinian inwardness which Taylor speaks of ${ }^{2}$.

So in accordance with Taylor's statement, I will hold in this paper that Descartes has borrowed this inward feature of Augustine's thought and developed from it a method of introspection which is widely used in his Meditations. More specifically speaking, my main aim will be to show that this inward approach to philosophical matters that Descartes learned from Augustine was of fundamental importance to the achievement of the first truth of his metaphysics, namely the cogito. However, despite the importance and ubiquity of Augustine's inwardness in Descartes' work on metaphysics, he does not acknowledge this fact anywhere. Descartes seems to have at least two complementary, although distinct reasons for acting this way towards his alleged Augustinian heritage: first, he wanted to establish a new beginning for

2 For a reading of the whole of the Meditations in a quite similar fashion, see Menn (1998). 


\section{Philosophy International Journal}

western thought, what precluded him from admitting any forerunner; second, he was really afraid that his Meditations were condemned by the Roman Catholic Church, given that he was tacitly adopting an Augustinian standpoint and thus indirectly refusing the traditional scholastic Aristotelian doctrine, without launching a direct attack on it, though.

Augustine's inwardness from which Descartes will develop his method of introspection consists in giving up concerns related to the material world and to what is issued from it through the bodily senses so that one can concentrate the whole of his attention on the immaterial principle that governs the human body, that is, the soul. According to Augustine's view, this 'inward turn' is essential to find out truth. That is why he strongly recommends: "Do not go outward. Return within yourself. In the inward man dwells truth ${ }^{3 "}$ ([1], 72). In De Trinitate, XII, 1, [2] Augustine distinguishes between the inner and the outer man. The outer man is the body, that is, all sort of things that we have in common with the beasts, including our senses, and even the memory storage of our images of sensory things. The inner man is of course the soul. And we must bear in mind that this distinction between the inner and the outer man is the cornerstone in Augustine's thought. For it has huge consequences for our spiritual purposes in life, because, as Taylor argues, on the road from the lower, bodily realm to the higher, divine realm, the crucial shift in direction passes through our attending to ourselves as essentially inner and immaterial ([3], p. 129).

So how does this inward approach work exactly and what does Augustine intend to achieve with it? Since the very core of Augustine's thought, both as a philosopher and as a clergyman, centered on a genuine "[...] desire to know God and the soul"4 ([4], I, 7), he begins his metaphysical reflections by attempting to gain knowledge of his own soul, and then he will strive to come to perceive God. In order to do this, he must first withdraw from the contemplation of bodies and enters into itself, so that it can perceive itself in the proper manner, from within, as a immaterial, not corporeal being; for this is a necessary condition "[...] to ascend to contemplate God as the perfect standard of the truth of its thoughts, and the source of its intellectual light" ([5], p. 141). So Augustine's appeals to our first-person experience in thinking aims at freeing us from the limitations of our corporeal condition and then raising us toward the vision of God ${ }^{5}$. In Confessions

3 Noli foras ire, in te ipsum redi; in interiore homine habitat veritas.

4 Deum et animam scire cupio.

5 As Taylor points out, the main reason that led Augustine to adopt an inward standpoint was for the sake of proving God's existence: "For Augustine, the path inward was only a step on the way upward. Something similar remains in Descartes, who also proves the existence of God starting from the self-understanding of the thinking agent" (Taylor, 1989, p. 156).
VII Augustine describes his long struggle to free himself from his immersion in the senses, so that he was able to think immaterial things, such as God and his own soul. It was thus that Augustine instated the turn to the self and the language of inwardness in western philosophy. It is on these grounds that Taylor claims that [...] it is hardly an exaggeration to say that it was Augustine who introduced the inwardness of radical reflexivity and bequeathed it to the Western tradition of thought" (Taylor, 1989, p. 131).

I believe that there is compelling textual evidence that Descartes has taken over this Augustinian inwardness and employed it to tackle the problems he was going to deal with in his Meditations and in particular to set forth his notion of cogito. In fact, the introspective or inward rhetoric can be found throughout the Meditations. So in the First Meditation, Descartes blames sensory perception for deceiving him and leading him astray in his search after truth. This assumption persuades the meditator to engage in a skeptical analysis that will prove decisive in setting him on the path to introspection: "The skeptical exercises of the First Meditation [...] give the Meditator a technique for 'withdrawing the mind from the senses ${ }^{6}[. .$.$] , withdrawing assent from everything perceived$ through images, so that the mind can use its internal selfknowledge" ([5], p. 253). As It was pointed out above, the act of 'withdrawing the mind from the senses' is the most important step toward inwardness. This move toward his inner nature or self provides Descartes with a method of introspection, which is employed in the First and Second Meditations, leading him from the 'skeptical doubt' to the cogito, the first truth achieved with this inward approach. Next, the method of introspection is manifestly and explicitly announced at the beginning of the Third Meditation, already suggesting the way whereby God's existence will be proved: "Talking just to myself and considering more deeply my own nature, I shall try little by little to reach a better knowledge of and a more familiarity with myself" ([6] [AT 7], p. 34). Likewise, at the very beginning of the Fourth Meditation Descartes emphasizes once again his commitment to the introspective method:

"In these past few days I have become used to keeping my mind away from the senses; and I have become strongly aware that very little is truly known about bodies, whereas much more is known about the human mind and still more about God. So now I find it easy to turn my mind away from objects of the senses and the imagination, towards objects of the intellect alone; [for] these are quite separate from matter" ([6][AT 7], pp. 52-53).

6 “[...] mentem a sensibus abducendam" (Descartes, 1996 [AT 7], p. 12). 'AT' refers to Descartes, René. Oeuvres de Descartes (Publiées par Charles Adam \& Paul Tannery, 11 vol.). Paris: Vrin, 1996. 


\section{Philosophy International Journal}

Finally, in the Sixth Meditation, drawing on the results of the Second Meditation, Descartes claims that he has a clear and distinct perception of the mind as a thinking, unextended thing. He then employs this perception to show that he, that is, his mind, an immaterial entity, is a substance different from body, a material one ([7], p. 379).

Notwithstanding the striking similarities between the method employed by both philosophers - as well as to a certain extent the aims pursued and the outcomes achieved by them -, "[...] Descartes persistently maintained that Augustine's writings were unknown to him" ([8], p. 34; see also [9], 2017). Regardless of Descartes' dismissal of his acquaintance with the works of Augustine and in face of the textual evidence that he must somehow have known quite well the thought of the African thinker, it is fair to ask how and why, after dedicating many years of his life to scientific research ${ }^{7}$, Descartes came to be truly interested in the thinking of a Father of the Early Church. I think that one can give a twofold answer to these questions. First, Descartes, aware of the shortcomings of the Peripatetic philosophy, which had dominated the intellectual life of Europe since the thirteenth century, wanted to replace this traditional system of thought by a new one. In fact, "[...] Descartes was much concerned to overthrow Aristotelianism" ([10], p. 122). Second, the intellectual environment in France was mostly influenced by the thought of Augustine. According to Menn ([4], p. 6), "[...] in France there was no rival to Augustine's prestige. He was an ineffaceable part of the intellectual background against which thinkers of the seventeenth century defined themselves"8. In Paris Descartes met many modern followers of Augustine. The most important among them was certainly the cardinal Pierre de Bérulle (1575-1629), the founder of the Oratory9. So almost inevitably "[a]round 1628, Descartes becomes acquainted with the Augustinian ideal of attentiveness to soul and God, and the Augustinian discipline of metaphysical reflection, associated with Bérulle and with his Congregation of the Oratory"10 ([5], p. 50). Thus Bérulle

7 This period refers to a kind of 'first phase' of his career, what we might call 'pre-Augustinian phase'. This pre-Augustinian phase begins with the meeting and collaboration with Isaac Beeckman (1588-1637). Beeckman was a Dutch natural philosopher who introduced Descartes to the corpuscularian and geometrical approach to natural phenomena. This phase, which began around 1618-19, ends with the unfinished work Rules for the direction of the mind (1628-9). The main concern of this period is with scientific and methodological issues.

8 Two good examples of this fact are the philosophers and theologians Antoine Arnauld (1612-1694) and Nicholas Malebranche (1638-1715), who started their careers as Augustinians and eventually became Cartesians, because both of them believed that Descartes himself was an Augustinian thinker.

9 Founded in 1611 in Paris, the Oratory was a religious institution that adopted the theological doctrine of Augustine.

10 Gaukroger agrees with Menn: "It was Bérulle, more than anyone else, who had been instrumental in the revival of the Augustinian view" seems to be a key figure for understanding the 'Augustinian turn', so to speak, in Descartes' thinking. For it is most likely that it was him who introduced Descartes to the thought of Augustine, since "Augustinianism was clearly an option open to Descartes, and Bérulle had possibly mentioned it to him at their meeting" ([11], p. 207). Reinforcing a little more the impact of this meeting on the 'conversion' of Descartes to Augustinianism, Menn reminds us that "no text prior to the conversation with Bérulle suggests that God and the soul are the first objects to be known ([5], pp. 210-1). To take this fact into consideration is of crucial importance to the interpretive hypothesis I am putting forward in this paper, since, as demonstrated in the Meditations, God and the soul are two immaterial or metaphysical entities which are known by introspection. Therefore, if these statements are correct, we may have in possession of strong evidence that not only the method of introspection, but also the metaphysical entities known by introspection (God and the soul) were suggested and borrowed by Descartes from the thought of Augustine ${ }^{11}$.

As important as to suggest that Descartes has taken over Augustinian inwardness and converted it into a method of introspection omnipresent in the Meditations is the question that concerns the precise manner in which Descartes has used Augustine's inwardness. We can also put it another way by asking why did Descartes need to resort to Augustinian inwardness to establish the first truth of his metaphysics (the cogito)? The interpretive hypothesis I want to put forth here to explain it consists in arguing that the French philosopher has seen in it a way to tacitly and indirectly undermine Aristotelian hylomorphism. Aristotle's hylomorphic ontology, which was widely accepted by scholastic thinkers, claims that every substance is a compound of form and matter. In a human being, for instance, the form is the soul or mind and the matter is the body. So Augustine's inwardness, being a way of getting the thinker away from the senses and the material world in order to turn his attention on his own soul, allows Descartes to bring about the radical distinction between the soul and the body. For, as I have already pointed out, this method enables him to "withdraw the mind from the senses" ([6] [at 7], p. 12), or, in Aristotelian terms, to isolate the form from the matter. That is, Augustinian inwardness fits pretty well Descartes' aim at distinguishing mind from body, for this methodological procedure enables him to establish a sharp distinction between matter (body) and form (mind). That is why I hold that the principal goal of Descartes' mind-body distinction - carried out through Augustinian inwardness -

(Gaukroger, 1995, p. 207).

11 As some scholars have recently showed (for instance, Teixeira, 2017; Wilson, 2009), there are many other features in Descartes' thought suggestive of close study and direct influence. If I am focusing here exclusively on introspection or inwardness, it is because, as I have pointed out above, it seems to be the most pervasive influence of Augustine over Descartes' Meditations. 


\section{Philosophy International Journal}

is to undermine the hylomorphic ontology and not only to merely show that the soul can exist apart from the body and that the soul is better known than the body, as he asserts in the title of the Second Meditation.

Thus, I believe that it is the transformation of Augustine's inwardness into a method of introspection that will allow Descartes to establish the real distinction between the soul, the form of human being, and its body, which corresponds to the matter (hyle) in Aristotle's hylomorphic ontology. What is the result achieved by undermining Aristotle's hylomorphic ontology? From the employment of Augustinian inwardness to undermine the scholastic Aristotelian hylomorphism will result the subjects of inherence of Descartes's notions of thinking substance (mind) and extended substance (body), the basic entities of his dualist ontology. As two independent substances, instead of being part of a hylomorphic unity, mind and body will be required to be the subject of inherence of some specific properties and qualities. As we will see just below, these properties and qualities are called 'simple natures' and they were put forward for the first time in the incomplete work Rules for the direction of the mind (1628). So Descartes possessed the properties and qualities he will use to shape the notions of res cogitans and res extensa much before he had worked out his doctrine of mind-body dualism $^{12}$ [12], that is, much before he had brought forth the subjects of inherence of his ontology (mind and body). However, by the time of working on the Rules Descartes had no interest in metaphysical issues whatsoever ${ }^{13}$ [13].

According to what Descartes states in the Rules, the simple natures are the objects of knowledge insofar as they present themselves immediately to the intellect and cannot be decomposed into simpler elements. So the simple natures are cognitive or epistemological notions which, in virtue of their simplicity, cannot undergo further analysis. Another characteristic of the simple natures is that they can be intuitively grasped by the mind, that is, the mind has direct access to them. Consequently, when we deal with simple natures "[...] we are concerned with things only in so far as they are perceived by the intellect, and so we term 'simple' only those things which we know so clearly and distinctly that they cannot be divided by the mind into other which are more distinctly known [...]"14 ([6][at 10], p. 418). As I will

12 Boyle correctly asserts that "[...] there is little evidence that at the time of writing the Rules Descartes had clearly formulated his doctrine of two substances" (Boyle, 2009, pp. 9-10).

13 As sustains Alquié, "[t]he Regulae does not therefore [...] contain any trace of metaphysics. On the contrary, the uncertainty which remains in that work about the nature of the mind, and its tendency to assume all truths under the same program shows plainly that, when he wrote the Regulae, Descartes' thought was still operating at a purely scientific level" (Alquié, 1950, p. 78).

14 After defining what simple nature is, Descartes goes show below, it will be by subordinating the simple natures to the subject of inherence issued from the mind-body distinction undertaken under the influence of Augustinian inwardness that Descartes will shape the metaphysical notion of res cogitans (thinking substance).

Jean-Luc Marion, a famous Descartes scholar, helps shade some light on what I have been trying to explain above about the role played by the simple natures in Descartes' ontology. Marion states that the simple natures will become the properties of the cogito in the Meditations. In fact, he is quite right in claiming that there is a strong similarity between what Descartes call 'intellectual simple natures' and the properties of the cogito. According to Marion,

[t]he parallelism here is quite obvious: cognitio ("knowledge") in the Regulae becomes cogitatio ("thought") in the Second Meditation, with a further echo later in the list in the term intelligens ("thing [...] that understands"). Dubium ("doubt") becomes dubitans ("that doubts"); ignorantia ("ignorance") probably corresponds to affirmans/negans ("which affirms and denies"); voluntatis actio ("the action of the will”) appears as the two modes of such action, volens/ nolens (is willing, is unwilling) ([14], p. 126).

This comparison between the simples natures and the properties of the cogito allows Marion to draw the seemingly undeniable conclusion that " $[\mathrm{t}]$ he essence of the res cogitans is defined in terms identical to the list of intellectual simple natures" ([14], p. 127). In other words, the cognitive notions that Descartes employed in the Rules to analyze human perceptual experience are used in the Meditations for the purpose of shaping the notion of cogito. And apparently the simple natures have fitted the concept of cogito pretty well.

I do agree with Marion's analysis except for one thing. According to his interpretation, to arrive at the notion of cogito Descartes does not need a subject of inherence or any

on to distinguish them into three categories. According to him, there are three different kinds of simple natures: the intellectual, the material and the common simple natures. The intellectual simple natures are those which can only be grasped by the understanding by means of its 'inborn' or 'natural light', such as the ideas we have of 'knowledge', 'doubt', 'ignorance', 'volition', etc. On the other hand, the material simple natures are the product of sensation and imagination, since they are properties of bodies, such as the notions of 'extension', 'shape', 'movement'. Finally, the common simple natures are subdivided into two groups: the 'reals' and the 'logicals'. The first ones are those which can be applied to both the material and the intellectual simple natures, such as 'existence', 'unity', 'duration', etc. The logical simple natures in turn are those which allow the other simple natures to be linked together by virtue of being 'common notions'. For instance, the fact that two terms that are themselves equal must be equal to a third term (Descartes, 1996, [AT 10], p. 419). 


\section{Philosophy International Journal}

kind of bearer of properties. On the contrary, after correctly asserting that the intellectual simple natures are the sources of the properties of the cogito, Marion goes on to argue that the element that is lacking in the Rules which will allow the cogito to emerge from the simple natures is not a subject of inherence that has prior existence to them; in his view, it depends only on the internal structure of the text and on the dynamics of its argumentation, that is, on the so-called 'order of reasons'. So to be raised to a metaphysical status the simple natures need nothing but to be put in the 'right order. For in Marion's assessment, "[w]ith the doctrine of the simple natures, the Regulae is already equipped with all the elements required for articulating the first proposition of metaphysics" ([13], p. 119). It is on these grounds that he claims that "the transition to metaphysics depends not on any new elements or concepts, but merely on the necessity which links them [the simple natures] together - and this necessity depends in turn on order" ([14], p. 119). This privileged condition for converting the simple natures into the cogito will only be found in the Meditations, where for the first time Descartes makes use of the 'order of reasons'. Thus for the French commentator, the 'order of reasons' is a necessary device and will suffice to shape the simple natures into the cogito. In other words, had Descartes articulated the simple natures in the adequate order, he would have seen the cogito emerging from these epistemological notions as early as in the Rules. Nothing else would have been required in Marion's view.

How does Marion account for the use of the 'order of reasons' in the constitution of the cogito? In Marion's view, the employment of 'order' in the Rules would have allowed Descartes to link together the intellectual simple natures 'to think (cogitare) or to doubt (dubitare)' with the real common simple nature 'to exist' (existere). The result of this process of linkage the simple natures in the right order would have led Descartes, already in the Rules, to find out the first metaphysical truth, i. e., the cogito. That is why Marion claims that "[...] the Regulae contains the elements of metaphysics (the intellectual simple natures) but not their ordering (their necessary lining with the common simple natures) [...]" ([14], p. 119). Therefore, in order to shape the notion of the cogito Descartes does not need anything else except to put the simple natures it consist of in the adequate order: "to think/to doubt" and "to exist". For this reason, Marion insists that "what is missing [in the Rules] is simply the capacity to establish a necessary order between the simple natures that make up the Cogito" ([14], p. 119). Marion came even to assert that his thesis has actually a broader range of application, for he thinks that it can be applied to the Meditations as a whole: "In fact the Meditations can be understood as a paradigmatic array of ordered groups of simple natures necessarily linked together". So if Marion's thesis is correct, we will be able to draw the conclusion that nothing new happened in Descartes' thought during the about twelve years that separates the Rules from the Meditations. That is, the Descartes of Marion has always been the same, except for the addition of 'order'.

Although at first sight Marion's interpretation may seem a promising way of employing Martial Gueroult's structuralist method $^{15}$ to account for the constitution of the cogito, I believe that it is nonetheless a problematic one. Indeed, in applying the structuralist method Marion overlooks the fact that he is turning cognitive notions - the simple natures - into a ontological notion - the res cogitans or thinking substance - without adding to them any further element except 'order' or rather a certain 'logical entailment', the 'order of reasons'. So I think that it is reasonable to ask how is it possible to pass from the epistemological realm of the simple natures to the metaphysical realm of the res cogitans? So in making use of Gueroult's structuralist method Marion believes to find within the text itself an internal principle that allowed Descartes to convert the simples natures (cognitive concepts) into the thinking substance (an ontological notion). Thus, as it is characteristic of the structuralist method proposed by Gueroult for the reading of Descartes' philosophy, a successful interpretation of Descartes' thought needs nothing else but a close attention to the internal structure of the text, following the 'order and connection' of its reasons. That is why Menn can arguably speak of "[...] Gueroult's anti-historical conclusions on the method of interpreting Descartes". For it fact " $[\mathrm{w}]$ hen Gueroult explains the text of the Meditations, he ignores the historical background completely" ([5], p. 12). And so does Marion. Therefore, Marion seems to be in complete agreement with Gueroult's fundamental principles of interpreting Descartes' philosophy as to what concerns the role of the simple natures in his metaphysics $[15,16]$.

I believe that it is possible to challenge Marion's structuralist-like interpretation by putting forward an alternative interpretive hypothesis, which presupposes the decisive influence of Augustine's inwardness on Descartes' thought. According to this hypothesis, the transformation of the simple natures into the cogito was only possible to be achieved after Descartes had undermined the scholastic Aristotelian hylomorphism. And this task was undertaken by means of a method of introspection that Descartes learned from Augustine's inwardness. In my view, in taking over Augustine's inward approach Descartes has provided himself with a powerful method of introspection that

15 In his famous book Descartes' philosophy interpreted according to the order of reasons Gueroult undertakes to explain the text of Descartes' Meditations from a new standpoint. In fact, his aim in this work is to analyze what he call the 'structures' of Cartesian argumentation, since, according to him, Descartes' “[...] philosophy is developed as a pure geometry, which owes all its certainty to the internal linkage of its reasons, without any reference to the external reality" (Gueroult, 1984, p. 7). In other words, for Gueroult, the meaning of the Meditations should be sought just in its logical structure. That is why the 'order of reasons' is so important in his analysis. 


\section{Philosophy International Journal}

allowed him to withdraw the mind from the senses. And so by analogy with the mind-body distinction he could conceive an ontology in which the form (the soul of a human being) can be understood as an entity completely independent of the matter (the body of a human being). It is in this way, by isolating the mind-form from the body-matter, that Descartes has undermined Aristotle's hylomorphic ontology. From now on, he is in possession of the subject of inherence or bearer of properties to which the simple natures will be subordinated. It is only at this point that the process described by Marion above can be correctly employed. In order words, it is by withdrawing the mind from the senses that Descartes will be able to conceive 'thought', the essence of the mind, as an ontological entity to which all other intellectual simple natures will be subordinated. The mere logical linkage of the simple natures proposed by Marion would by no means be able to raise 'thought' to the ontological role that it plays in Descartes' res cogitans. That is why in my analysis Augustine's inwardness is so important to understand the constitution of the cogito. In fact, Augustinian inwardness provides a clue to explain two very fundamental things that Marion's reading is unable to account for. Augustine' inwardness helps us understand not only how 'thought' was raised to the ontological role it plays in Descartes' metaphysics, but also why it has ontological priority among the other intellectual simple natures. It is on these grounds that I think that my interpretation is superior to Marion's.

\section{References}

1. Augustine, De vera religione.

2. Augustine. De Trinitate.

3. Taylor C (1992) The sources of the self: The making of modern identity. Cambridge: Cambridge University Press.

4. Augustine. Soliloquia.
5. Menn S (1998) Descartes and Augustine. Cambridge: Cambridge University Press.

6. Descartes R (1996) Oeuvres de Descartes.11 ${ }^{\text {th }}$ (Vol.), Charles Adam \& Paul Tannery, Paris: Vrin.

7. Rozemond M (2011) Descartes's Dualism. In: Broughton J, Carriero JP (Eds.), A Companion to Descartes, Malden, MA: Willey-Blackwell, pp: 372-389.

8. Wilson C (2011) Descartes and Augustine. In: Broughton J, Carriero JP (Eds.), A Companion to Descartes, Malden, MA: Willey-Blackwell, pp: 33-51.

9. Teixeira W (2017) The Metaphysics of Augustine and the foundation of the Cartesian science. Cadernos Espinosanos. São Paulo, pp: 291-313.

10. Rozemond M (1998) Descartes' dualism. Cambridge: Harvard University Press.

11. Gaukroger S (1995) Descartes: an intellectual biography. Oxford: Claredon Press.

12. Boyle D (2009) Descartes on innate ideas: New York: Continuum.

13. Alquié $\mathrm{F}$ (1950) La découverte métaphysique de l'homme chez Descartes. Paris: Presse Universitaire de France.

14. Marion JL (1992) Cartesian metaphysics and the role of simple natures. In: Cottingham J (Ed.), Cambridge Companion to Descartes, Cambridge: Cambridge University Press, pp: 115-139.

15. Guéroult M (1953) Descartes selon l'ordre des raisons. Paris: Montaigne.

16. Gueroult M (1984) Descartes' philosophy interpreted according to the order of reasons. Roger Ariew (Transl). Minneapolis: University of Minnesota Press. 